Article

\title{
Closing the Gap between Climate Information Producers and Users: Assessment of Needs and Uptake in Senegal
}

\author{
Issa Ouedraogo ${ }^{1, *}$, Ndeye Seynabou Diouf $^{1}$, Mathieu Ouédraogo ${ }^{1}{ }^{\circledR}$, Ousmane Ndiaye $^{2}$ \\ and Robert B. Zougmoré 1 \\ 1 The CGIAR Program on Climate Change, Agriculture and Food Security (CCAFS), ICRISAT West \& Central \\ Africa Regional Office, BP 320 Bamako, Mali; S.Diouf@cgiar.org (N.S.D.); M.Ouedraogo@cgiar.org (M.O.); \\ R.Zougmore@cgiar.org (R.Z.) \\ 2 Agence Nationale de l'Aviation Civile et de la Météorologie (ANACIM), Aéroport Léopold Sedar Senghor, \\ BP 8257 Dakar-Yoff, Senegal; ousmane.ndiaye@anacim.sn \\ * Correspondence: i.ouedraogo@cgiar.org; Tel.: +221-771-562-450
}

Received: 17 December 2017; Accepted: 15 February 2018; Published: 19 February 2018

\begin{abstract}
West Africa is a very vulnerable part of the world to the impacts of climate change due to a combination of exposure and low adaptive capacity. Climate change has induced an increase in rainfall variability which in turn has affected the availability of water resources, ecosystem services and agricultural production. To adapt to the increased aridity, farmers have used indigenous and modern coping strategies such as soil and water conservation techniques, the use of drought-tolerant crops and varieties, crop diversification, etc., and lately, climate information services (CIS). The latter, according to the discourses, has positively contributed to suitable decision-making in terms of farming, pastoral and fishing management systems. However, the scientific documentation of the engagement approaches, the uptake of the CIS and the ways the delivered information is being used, as well as feedback from the users, is lacking. Additionally, in most of the cases where CIS are introduced, the disconnect between the users and producers of the CIS seems to undercut large-scale uptake. The objective of this paper is to examine the approach used to involve stakeholders in the CIS uptake process in Senegal. We analyzed the experiences and lessons learnt in the country where various CIS products were introduced using participatory methods (stakeholder consultations, interviews, field demonstrations, training workshops, etc.) and innovative stressors (SMS, voice messages, radios, mobile applications, etc.) to effectively involve producers, technicians and policy-makers. Results showed that 16 relevant CIS have been produced out of 27 identified by the various users; 11 CIS diffusion channels have been developed out of 13 requested; 27 climate advisory bodies (MWGs) have been created in 27 districts out of 30 districts in the study zone; about 6800 users have been trained directly and indirectly to effectively use CIS and about 8500 people are receiving CIS via SMS, voice messaging and emails. The opportunities for CIS uptake as well as the challenges that may impede the long-term sustainability of CIS upscaling in the country are highlighted. Recommendations that will improve and sustain the governance system of CIS in Senegal and the rest of West Africa include the involvement of private sectors in the chain of production, delivery and training, and the inciting of producers to largely subscribe to the weather-based index insurance.
\end{abstract}

Keywords: climate risk management; adaptation; communication channels; capacity building; West Africa

\section{Introduction}

Recent studies have disclosed that West Africa (WA) is a very vulnerable part of the world to the impacts of climate change due to a combination of exposure and low adaptive capacity [1-3]. 
In both the low-emission scenario (representing a $2{ }^{\circ} \mathrm{C}$ world increase) and the high-emission scenario (representing a $4{ }^{\circ} \mathrm{C}$ world increase), West African temperatures will increase to about $1.5^{\circ} \mathrm{C}$ by 2050 and $5{ }^{\circ} \mathrm{C}$ above the 1951-1980 baseline, respectively, and will remain at this level until the end of the century $[3,4]$. This temperature increase will exacerbate the rainfall patterns, already characterized by a very high variability. This in turn will affect water resource availability, ecosystem services and agricultural production [5,6]. The population of WA is expected to reach 600 million people in 2050 [7]. Currently, the agricultural sector in WA employs $60 \%$ of the active labor force but accounts only for $35 \%$ of WA's gross domestic product (GDP) [4]. Actual crop yield achieved remains below the potential, with inadequate water and nutrients being the major limiting factors [3,8]. Agricultural production in this part of the world is particularly affected by the effects of climate change, with rain-fed agriculture accounting for approximately $96 \%$ of overall crop production [6].

To adapt to the increased aridity in West Africa, farmers have used indigenous and modern coping strategies. Examples of these techniques include soil and water conservation practices [9,10], agricultural water harvesting techniques [11-14] and, very recently, climate information services or early warning systems [15-17]. The introduction of weather forecasting systems for risk management in agricultural practices sounds relevant as it provides timely weather information, helping producers to take appropriate decisions [17]. Here again, WA is a region where accurate climate projections are limited due to multiple factors such as poor observational records, high inter-annual climate variability and a low level of investment in climate science $[16,18]$. Following the recognition of the importance of climate information to address climate-resilient development issues, there is a growing interest in building the national level capacity for climate information provision, delivery and efficient uses [19-21]. The climate information service is concerned with the timely provision of tailored climate-related knowledge and information that can be used to reduce losses and enhance profits. However, knowledge of suitable approaches used to effectively engage people on the identification of the needs and use of CIS and products, the level of uptake by users and on how the information delivered is being used, as well as the feedbacks and demands from users in terms of type and time-frame, is scarce. Moreover, in most of the cases where CIS is introduced, the disconnect between users and producers of the CIS has undercut large-scale uptake [17,22,23].

In Senegal, for instance, various adaptation techniques are being used such as drought-resistant crop varieties, soil and water conservation techniques, traditional pruning and fertilizing techniques, different planting dates [24], agroforestry and assisted natural regeneration system [25]. More recently, important investments have been deployed to enable the national body in charge of meteorological data management to produce and disseminate required climate information services and to train users to understand and efficiently integrate CIS into their management systems [26]. Beneficiaries of the CIS are farming, pastoralist and fishing communities which are affected by the decreasing rainfall distribution in space and time, the shrinking rainy season and recurrent occurrence of climate extreme events. The objective of this paper is to analyze approaches used to engage producers in the uptake of CIS in Senegal. Three specific research questions are examined in this paper: (i) What specific climate information and diffusion channels are required by the various stakeholders? (ii) What is the evidence that support the effective use of CIS by beneficiaries? (iii) What are the challenges and opportunities for a large-scale adoption of CIS use in Senegal?

\section{Materials and Methods}

\subsection{Characteristics of the Study Zone}

The study was conducted in Senegal, in 30 districts within 12 regions with high agricultural and pastoral potentialities and coastal regions with high artisanal fishery activities (Figure 1). Agricultural and livestock production are the main economic activities in Senegal, representing 17.5\% of the gross domestic product (GDP) and employing 69\% of the population [27]. The agricultural sector is characterized by a combination of poor soil and weather conditions, a lack of infrastructure and 
access to quality seeds and fertilizer that have left the sector underdeveloped and unable to meet the food requirements of the 15 million people [28]. As a result, the country heavily relies on food imports, especially rice, which is the population's main staple crop. The imported rice accounts for $65 \%$ of the national consumption [29]. The sector, however, has the potential to grow and feed the population provided due attention is paid to agricultural input facilities such as fertilizers, improved crop varieties, credit, equipment, climate information services and relevant agro-meteorological advisories. Rainfall is the key factor that determines agriculture production as less than 5\% of land cultivated is under irrigation [28]. The agricultural economy is characterized by the dominance of smallholder farmers cultivating millet, sorghum, maize and rice for subsistence purposes.

The number of artisanal fishermen in the country has increased from 126,800 in 1980 to 181,200 in 2014 and to nearly 200,000 in 2017 [30]. This boom has raised the challenges in the sector, notably the scarcity of the fish resources, forcing fishermen to travel long distances across the sea for several days and, more often, to illegally fish in foreign territorial waters in The Gambia, Guinea, and Mauritania. With the increase in extreme weather events (frequent high tides and swells, decreased visibility) due to climate change, many fishermen are reported dead every year. The statistics from the office of the fisheries protection and monitoring (DPSP) reveal that in 2013, 19 fishermen died at sea and 70 disappeared; in 2014, 22 died and 94 disappeared, and in 2015, 23 fishermen died and 73 disappeared. These unfortunate cases have called for the introduction of climate information services in the fisheries sector to prevent the artisanal fishing communities from being affected by climate hazards while at sea.

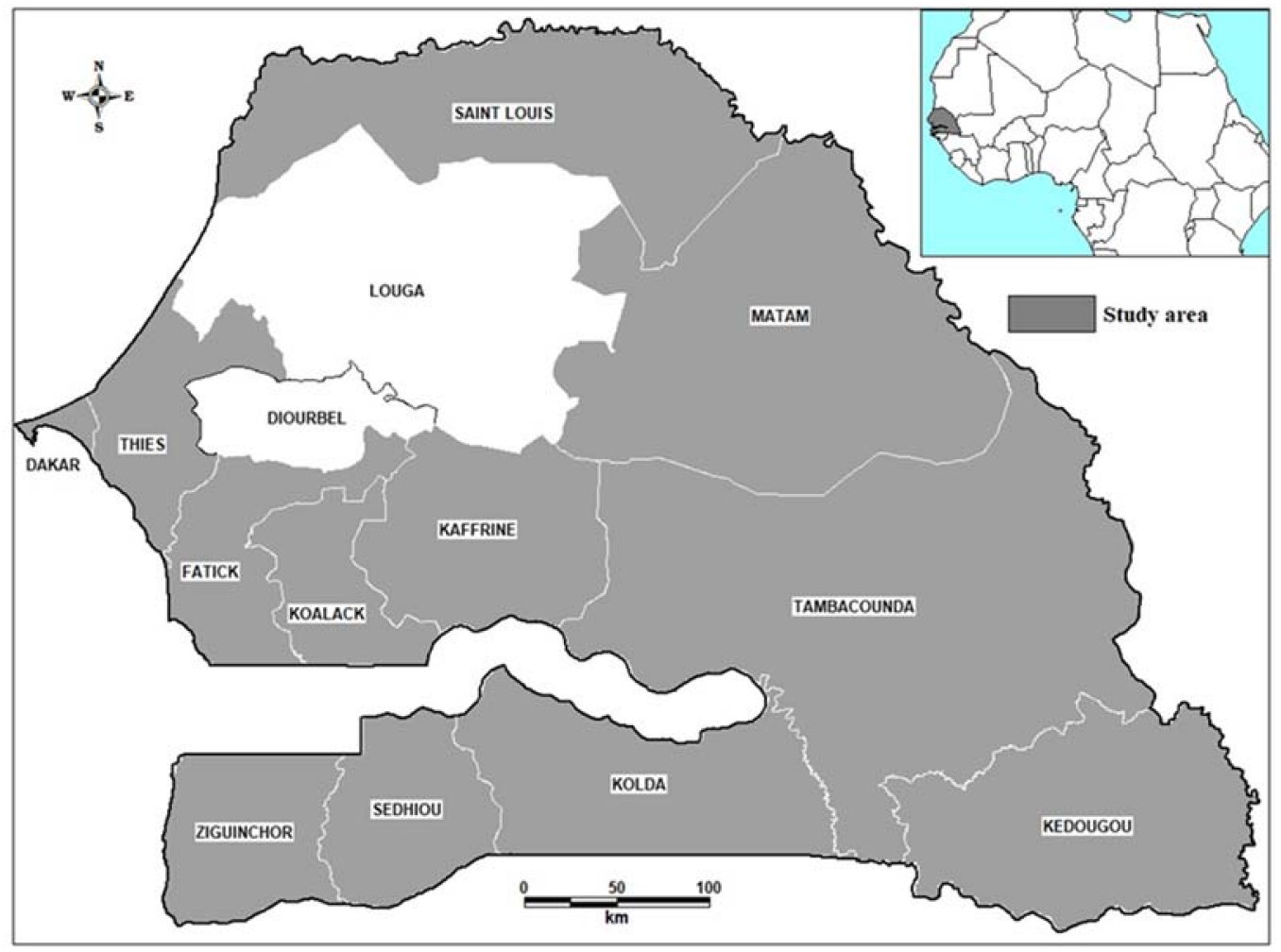

Figure 1. Location of the study zone (source: from authors).

\subsection{Methodological Approach}

\subsubsection{Needs Assessments and End-User Engagement}

The need assessment for relevant CIS and CIS dissemination channels was done in April 2016 through a three-day stakeholder consultation workshop gathering 75 people and interviews with 25 key resources persons. The purpose of the stakeholder consultation was to give to the various categories 
of stakeholders the opportunity to think about what climate information would be useful to inform the decision-making for their activities. Participants included people from different backgrounds, institutions and localities such as lead farmers, pastoralists, fishermen, technicians from the ministries of relevance (agriculture, animal husbandry, fisheries), experts from the meteorological office and from relevant non-governmental organization and technicians from communication services (community radios, televisions, phone companies, etc.). Participants were split into three groups, the first focused on agriculture, the second on the livestock sector and the third on the fisheries sector. Each group was asked to identify what climate information could usefully contribute to more robust planning and decision-making in the context of climate variability and change, and thus to produce a list of information needed and to identify relevant diffusion channels that enable timely access to CIS by users. The spatial and temporal resolution of each identified CIS as well as the coverage scale of the diffusion channels, the strengths and weaknesses of the identified CIS and channel were examined. The interviews concerned key respondents such as technicians in charge of climate data management and CIS production, experts from the crop production, livestock, and fisheries sub-sectors; directors of the community radios and experts from the mobile phone companies to find out the relevance and the feasibility of the CIS and communication channels been identified.

Three different tools were used to stimulate the engagement of the producers and the local authorities in the adoption of CIS: (1) the creation of 27 multi-disciplinary working groups (MWGs); (2) 27 participatory training workshops with the producers; and (3) the implementation of the field demonstration with controlled CIS use by 62 lead-farmers.

The multi-disciplinary working group (MWG) was an initiative of the Agro-Hydro-Meteorology (Agrhymet for the Sahel) national committee and constitutes a decisive and inclusive tool for CIS development, diffusion and uptake at the district scale. Members of MWGs include all relevant state extension technical services and relevant local organizations within the districts. The mission of the MWG is to ensure the close monitoring of the climate phenomena and to alert timely, competent structures in order to prevent potential risks. Services in charge of water resources, agriculture, forestry, the medias and the producers' organizations are involved in the MWGs' activities and meetings. They receive meteorological information such as the seasonal, weekly and instant forecasts from the meteorological office and tailor the information using the updates from the actual ground reality with regards to the areas of competency of each participating service. They meet three times a month during the cropping season to discuss and take action for better planning of the farming activities within the district for the next 10-day period. Each MWG should have a legal status and be led by the Prefect of the district.

The participative training workshop approach was initiated during the study period. It was used to train the lead-farmers in order to break the gap between the CIS producers and the users, to build trust for successful climate risk management and to optimize the efficiency of the uptake of the CIS being diffused. In the agricultural sector, the training modules consisted of climate change (adaptation and mitigation), the indigenous seasonal forecast, scientific seasonal forecast, the diffusion of CIS and the use and maintenance of manual rain gauges. With regards to the fisheries sector, the participative trainings cover sessions on security on sea (use of life jackets); climate system and climate change that govern the behavior of the oceans (tides, swell, visibility, etc.) and climate information services and its utilities for the security of fishermen at sea.

The field demonstration approach is an innovative, participatory and interactive learning approach that emphasizes problem-solving and discovery-based learning. The field demonstration was initiated during the study period and aims to build farmers' capacity to analyze their production systems, identify problems, test possible solutions, and eventually encourage the members of their communities to adopt the practices most suitable to their farming systems. For the present case, a selected 62 farmers had the opportunity to practice and test/evaluate sustainable farming technologies and introduce CIS by comparing their conventional technologies developed with their own tradition and culture. The field demonstration was facilitated by the extension staff and by the 
access to relevant CIS. The method emphasizes group observation, discussion, analysis, presentation, and collective decision-making and actions. The basic component of the field demonstration, similarly to the farmer field school approach, is setting up of a participatory comparative experiment (PCE), commonly referred to as participatory technology development (PTD), whereby the farmers put the concept into practice [31].

\subsubsection{Evaluation of CIS Uptake among Exposers}

The evaluation of CIS use was done using three different methodological approaches: (1) interviews with selected farmers who had access to CIS; (2) evaluation workshops with the farmers; and (3) evaluation of the performance of the MWGs.

A semi-structured questionnaire was developed to collect data from farmers and fishermen who received CIS via SMS and voice messages between May and June 2017 (the beginning of the rainy season) and October-November 2017 (end of the rainy season). A total of 289 farmers and 257 fishermen were randomly selected in the database. The questionnaire was administered using phone calls. The purpose was to assess the decisions taken by the beneficiaries after the reception of the CIS and the level of satisfaction for their activities. CIS communicated to farmers were concerned with the seasonal forecast, the optimal sowing dates, the instant rainfall occurrence forecasts, heavy wind forecasts and the cessation dates of the rain. CIS diffused to fishermen communities were mostly about high swell events that usually cause damages to fishermen's life and fishing materials.

In addition, three workshops with the farmers were held in Ziguinchor, Sedhiou and Kolda in August 2017 to record interesting decisions that they have taken following the reception of the diffused CIS, and to evaluate the trainings they received prior to the start of the rainy season. This also offered a venue to retrieve constructive suggestions and options that would improve the trainings for the next coming years from them and, finally, to record interesting decisions that they have taken following the reception of the diffused CIS.

We assessed the performance of the MWGs through two major functions: the existence of a prefectural signed decree and the fulfillment of the decadal regular meetings during the rainy seasons. From the onset to the cessation times of the 2017 rainy season, all the meeting dates and reports of all created MWGs were recorded and examined at the end of the rainy season.

\section{Results}

\subsection{CIS Needed vs. CIS Produced}

Relevant CIS identified per sector of activities by the participants during the stakeholder consultation and by the respondents of the interviews with key-resource people are presented in Table 1. Various CIS have been identified by the stakeholders from the three sectors of interest. For the farming activities, 16 CIS believed to contribute to suitable decision-makings for improving crop productivity at the local and regional scales have been identified. The most important are the seasonal forecast, the onset and cessation dates, the optimal sowing dates, daily rainfall forecasts, the false starts, the cumulative rainfall and the dry and wet-spells. While most identified CIS are needed many times during the rainy season, the seasonal, onset and cessation dates forecasts are required once in a year prior to the beginning of the season. All CIS are required at a much-downscaled resolution.

In the livestock management sector, five CIS have been identified, of which the three most important are the fodder and water resource availability forecasts throughout the year and the potential lightning zones during the rainy season to help avoid risk hazards generally caused by the lightning, cited as important source of animal loss. Participants who focused on the fisheries sectors came out with six relevant CIS for the safety management of the sector: swell, tide and visibility forecasts, wind, lightning and sea surface temperature forecasts. All these CIS need to be produced and diffused daily for the different coastal areas. 
Table 1. Assessment of climate information services (CIS) needs by stakeholders (source: from authors).

\begin{tabular}{|c|c|c|c|c|}
\hline Rank & Requested CIS & Timing & Frequency & Spatial Resolution \\
\hline \multicolumn{5}{|c|}{ Agricultural Sector } \\
\hline 1 & Seasonal forecast & May-June & Once a year & Local and regional \\
\hline 2 & Onset date & May & Once a year & Local and regional \\
\hline 3 & Cessation date & May & Once a year & Local and regional \\
\hline 4 & Optimal sowing date & May-June & Once a year & Local and regional \\
\hline 5 & Daily rain forecast & May-Sept & Daily & Local and regional \\
\hline 6 & False start & May-June & When relevant & Local and regional \\
\hline 7 & Cumulative rainfall & May-Sept & Decadal & Local and regional \\
\hline 8 & Dry spells & May-Sept & Decadal & Local and regional \\
\hline 9 & Wet spells & May-Sept & Decadal & Local and regional \\
\hline 10 & Moisture & May-Sept & Decadal & Local and regional \\
\hline 11 & Temperature forecast & May-Sept & Daily & Local and regional \\
\hline 12 & Wind forecast & May-Sept & Daily & Local and regional \\
\hline 13 & Evapotranspiration (ETP) & May-Sept & Decadal & Local and regional \\
\hline 14 & Insolation & May-Sept & Daily & Local and regional \\
\hline 15 & Off-season rains & Sept-Oct & When relevant & Local and regional \\
\hline 16 & On-farm forecast & May-Sept & Daily & Local \\
\hline \multicolumn{5}{|c|}{ Livestock Management Sector } \\
\hline 1 & Fodder availability & Year-round & Decadal & $\begin{array}{l}\text { Regional and } \\
\text { national }\end{array}$ \\
\hline 2 & Water resource availability & Year-round & Decadal & $\begin{array}{l}\text { Regional and } \\
\text { national }\end{array}$ \\
\hline 3 & Potential lightning zones & May-Sept & Daily & Local \\
\hline 4 & $\begin{array}{l}\text { Potential diseases } \\
\text { occurrence zones }\end{array}$ & Year-round & Decadal & $\begin{array}{l}\text { Regional and } \\
\text { national }\end{array}$ \\
\hline 5 & Transhumance corridors & Year-round & Decadal & $\begin{array}{l}\text { Regional and } \\
\text { national }\end{array}$ \\
\hline \multicolumn{5}{|c|}{ Fisheries Sector } \\
\hline 1 & High swell forecast & Year-round & daily & Costal zones \\
\hline 2 & High tides forecast & Year-round & daily & Costal zones \\
\hline 3 & Visibility forecast & Year-round & daily & Costal zones \\
\hline 4 & Wind forecast & Year-round & daily & Costal zones \\
\hline 5 & Potential lightning zones & Year-round & daily & Costal zones \\
\hline 6 & Sea Surface Temperature & Year-round & daily & Costal zones \\
\hline
\end{tabular}

In response to these requests, 11 CIS of relevance for the farming activities and five CIS for the fisheries sector have been produced and diffused (Figure 2). Five other CIS in the farming sector (optimal sowing date, moisture, evapotranspiration, insolation, on-farm forecasts) and one in the fisheries sector (potential lightning zones in the sea) remain to be produced. However, no CIS has been produced in the livestock breading sector. 


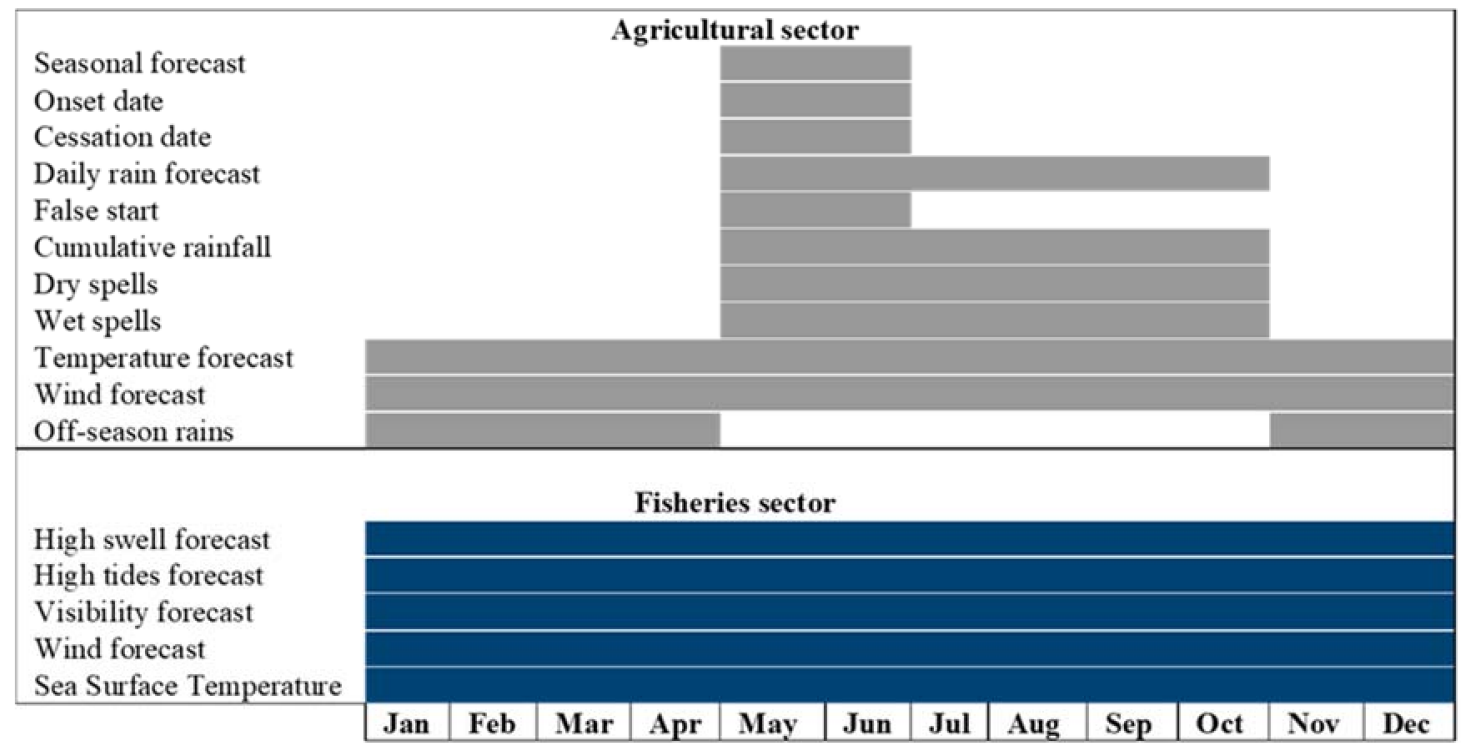

Figure 2. Diffusion timing for produced CIS (source: from authors).

\subsection{CIS Diffusion Channels vs. Channels Developed}

Following the request from the CIS users during the stakeholder consultation, different communication channels have been developed to diffuse CIS within and beyond the study zone. Table 2 shows the list of channels and highlights the categories of beneficiaries, the strengths and the weaknesses of each of the channels as analyzed by stakeholders. Eleven communication channels have been operationalized and two other channels, namely the digital communication screen and the unstructured supplementary service data (USSD) system, are still under development.

To date, there are 106 community radios that promptly diffuse CIS to the different communities, of which 50 are located in the study site. The technicians of the community radios have received due training to develop dedicated radio programs on CIS and to diffuse them in a time suitable to the producers and in local jargon. The community radios play three distinct roles for CIS use. In addition to diffusing CIS received from the CIS forecasting center, they also collect climate data through manual rain gauges provided by the CIS diffusion center. The rainfall data collected as well as the accrued data is frequently communicated to users.

About 962 leaders in the fisheries communities and 1829 lead-farmers are directly receiving CIS via the short messages service (SMS). These leaders have also the mandate to share the CIS they regularly receive with the members of their respective communities or groups. The voice messaging system was developed in 2017 to communicate CIS to farming and pastoralist communities, following the ascertainment that, in remote rural areas, most of the farmers are illiterate and cannot read and understand CIS via SMS. The voice messaging system diffuses CIS in local languages (mainly Wolof, spoken by all Senegalese). To date, the 1829 lead-farmers are receiving CIS from their mobile phones via both the SMS and the voice call platforms. An additional 5323 farmers have received CIS from the lead-farmers in the study site. The email platform is used to send climate-related information (CIS, bulletins, etc.) to the officials (ministries), technicians of the public extension services and the community radios for a large diffusion to their constituencies. In total 308 individuals are regularly receiving relevant CIS through emails. 
Table 2. Channels developed for CIS transmission (source: from authors).

\begin{tabular}{|c|c|c|c|c|}
\hline Identified CIS Diffusion Channels & Operational & Beneficiaries & Strengths & Weaknesses \\
\hline Community radios & YES & All users & $\begin{array}{c}\text { Accessible } \\
\text { Local language }\end{array}$ & Weak coverage \\
\hline $\begin{array}{c}\text { Televisions } \\
\text { Communication screen (ports) }\end{array}$ & $\begin{array}{l}\text { YES } \\
\text { NO }\end{array}$ & $\begin{array}{l}\text { All users } \\
\text { Fishermen }\end{array}$ & Visual information & Weak coverage \\
\hline $\begin{array}{c}\text { Mobile devices: } \\
\text { SMS } \\
\text { Vocal message in local language } \\
\text { USSD } \\
\text { Mobile application (Meteo Senegal) }\end{array}$ & $\begin{array}{l}\text { YES } \\
\text { YES } \\
\text { NO } \\
\text { YES }\end{array}$ & All users & $\begin{array}{l}\text { Targeted information, } \\
\text { Interactive }\end{array}$ & $\begin{array}{c}\text { Not accessible to all } \\
\text { beneficiaries }\end{array}$ \\
\hline 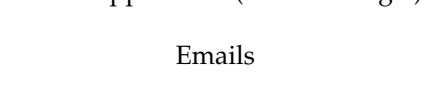 & YES & $\begin{array}{l}\text { Technical services, } \\
\text { Radios, Officials } \\
\text { Producers group }\end{array}$ & $\begin{array}{l}\text { Easy to understand } \\
\text { Interactive }\end{array}$ & Limited access \\
\hline Website (www.ANACIM.sn) & YES & All users & $\begin{array}{c}\text { Accessible } \\
\text { Full information }\end{array}$ & $\begin{array}{l}\text { Lack of accuracy } \\
\text { Limited access }\end{array}$ \\
\hline Call service & YES & All users & $\begin{array}{l}\text { Interactive, direct } \\
\text { feedback }\end{array}$ & $\begin{array}{l}\text { Only one line } \\
\text { Very crowded }\end{array}$ \\
\hline Itinerant Seminars & YES & All users & Interactive & Costly and sporadic \\
\hline
\end{tabular}

\subsection{MWGs Created vs. MWGs' Functionality}

As explained, the MWGs constitute a decisive and inclusive tool for CIS development, diffusion and uptake at the district scale in the sense that they have the mandate to ensure the close monitoring of the climate phenomena and to alert timely, competent structures in order to prevent potential risks in the agricultural sector. Figure 3 presents the location of the MWGs being created during the study period. In total, 27 MWGs have been created in 27 districts out of 30 districts in the study area. The performance evaluation of the created MWGs revealed that in 2017, 21 MWGs have held on average six meetings (Figure 4). The most operational MWGs are those that had at least seven regular meetings. These are Bambey, Niakhar, Thies, Tivaoune, Kédougou, Saraya, Salemata, Podor, Kolda and Vélingara. They are followed by those that held between five and six regular meetings: Goudiry, Linguere, Kaffrine and Tambacounda.

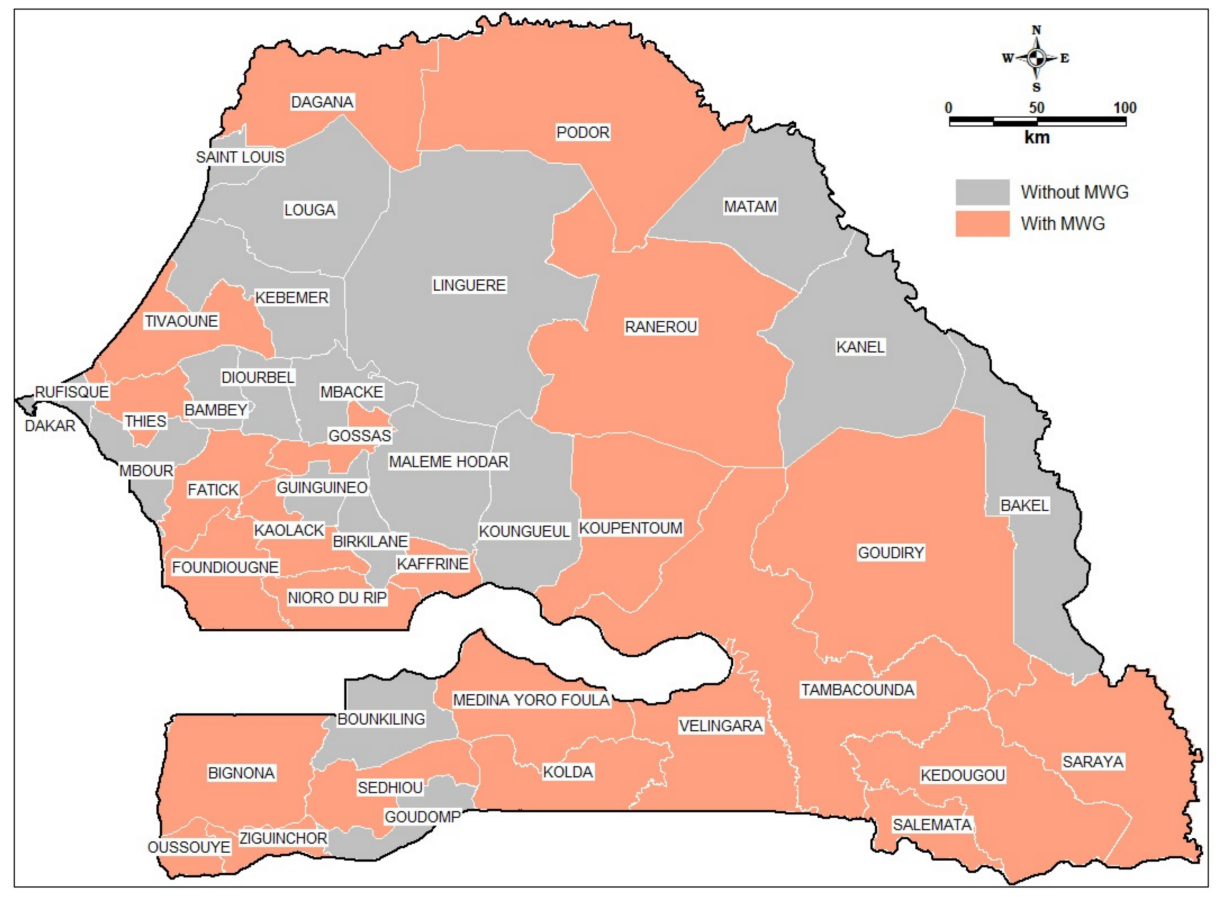

Figure 3. Pictorial representation of the multi-disciplinary working groups (MWGs) created during the study period (source: from authors). 


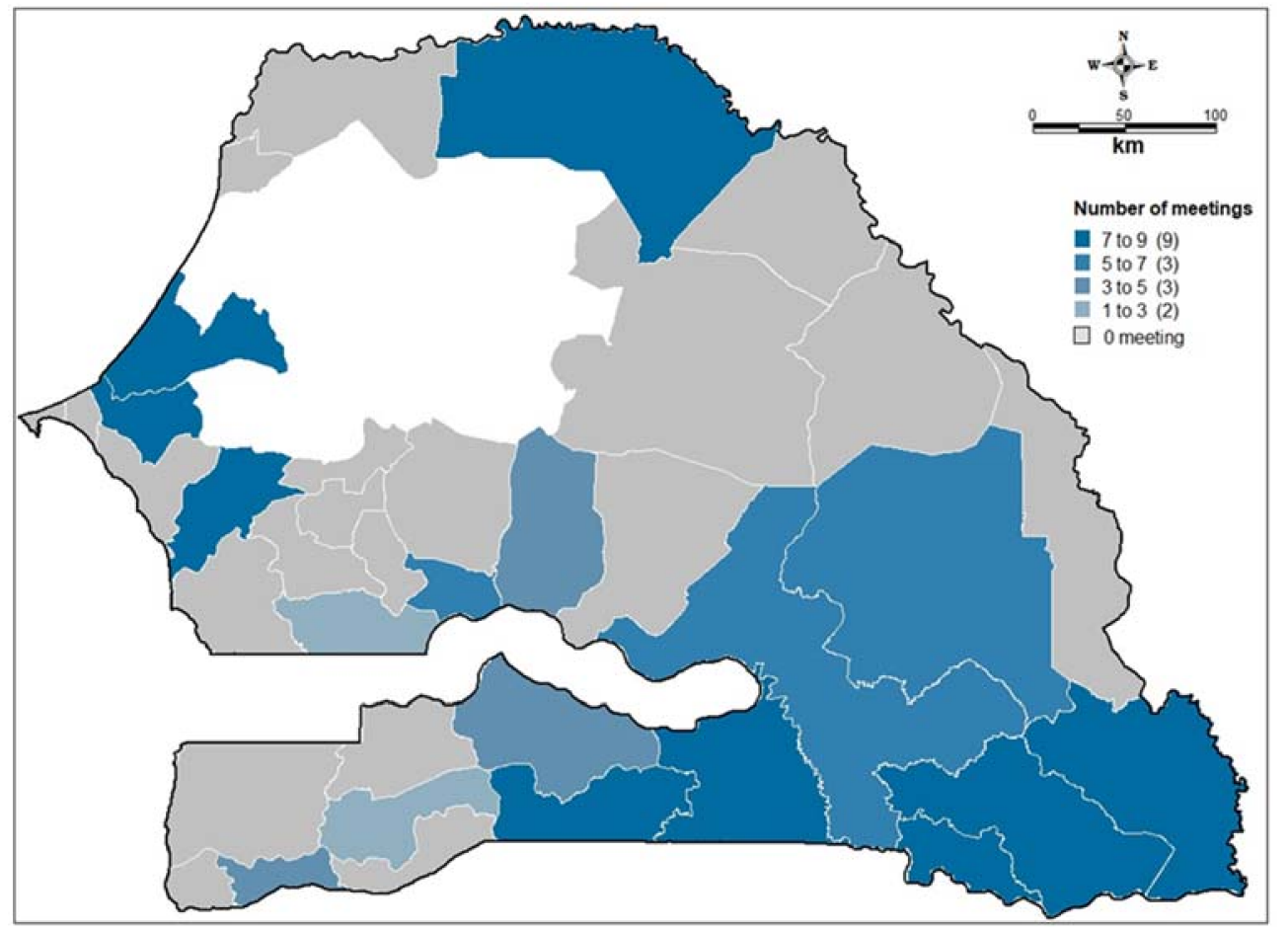

Figure 4. Functionality status of the MWGs (source: from authors).

\subsection{Magnitude of the Trainings on the Ground}

In the farming sector, 27 trainings took place in 23 districts (Figure 5). In total, 1439 people attended the trainings, of which 1124 were producers, 282 were technicians and 32 from the media (radios and written press). In addition to those who directly benefited from the training, 5323 other people have been trained by the lead-farmers who had the first and direct trainings. Among the beneficiaries of the trainings, $16 \%$ are women. For farmers to gain the full benefit of the training, they should be trained prior to the onset of the rainy season. In so doing, they have time to prepare themselves in advance to face the upcoming rainy season and also to share the knowledge and skills they got with the members of their groups or communities. The trainings were planned following the south to north progress of the onset of the raining season (Figure 5). Unfortunately, due to poor planning, some districts in the south, namely Ziguinchor, Bignona, Boukling and Sedhiou received the training in the middle of the rainy season (Figure 5). However, these trainings are still useful, as the skills built will serve for the coming farming periods.

The trainings in the fisheries sector targeted the leaders of the local artisanal fishers' council (CLPA). Lead-members from ten CLPAs in five different districts-Bignona, Oussouye and Ziguinchor in the Region of Ziguinchor, and Fatick and Foundiougne in the Region of Fatick (out of 40 CLPAs) - benefited from trainings on security at sea. In total, 439 people attended the trainings, from which 369 were fishermen, 63 were technicians and 12 were journalists (Table 3). Among the fishermen being trained, $4 \%$ only were female.

During the different trainings (farmers and fishermen), the phone numbers of the participants and their relevant profile information were recorded to supply the database of the SMS and voice call platforms. 


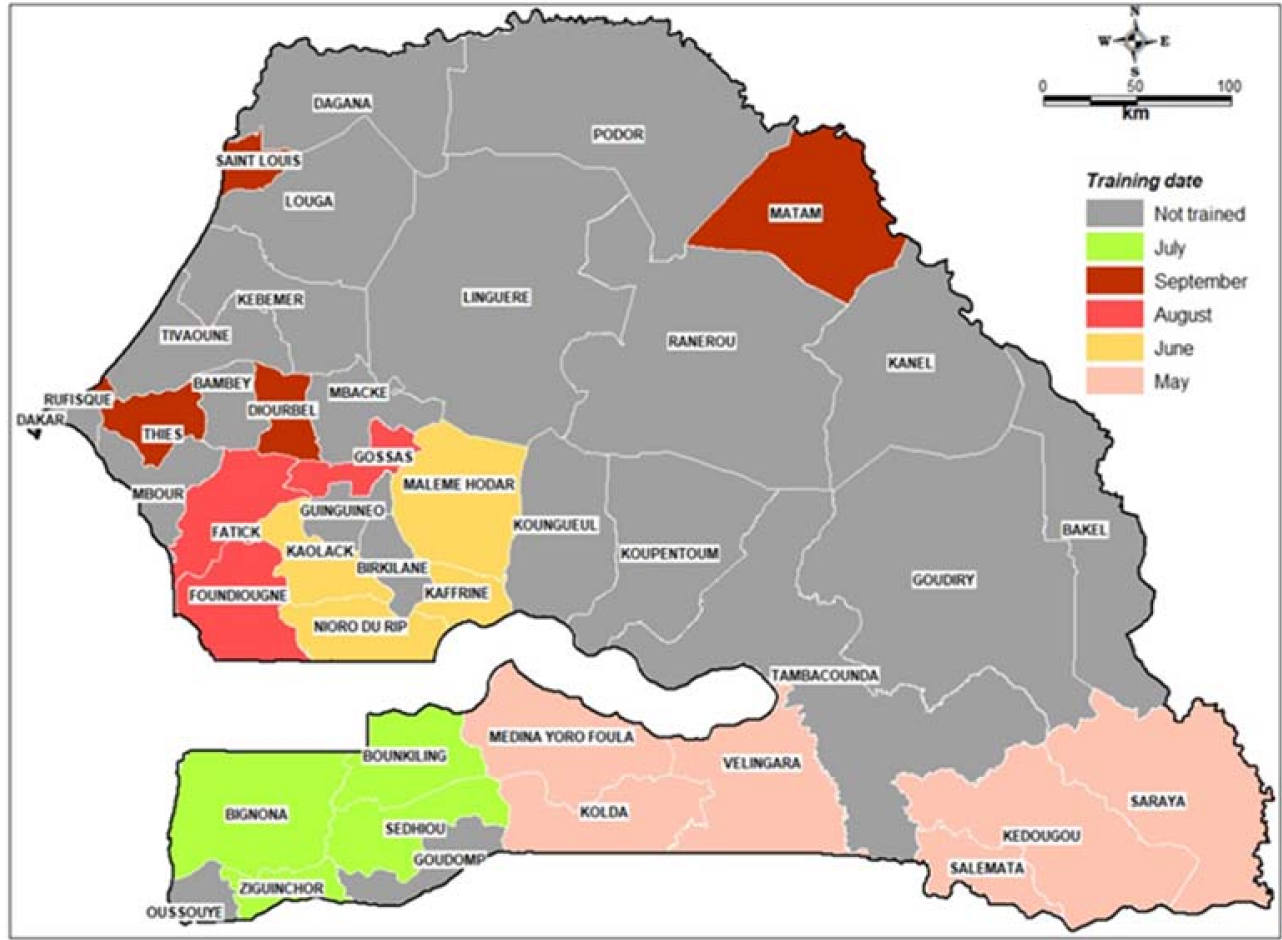

Figure 5. Pictorial representation of the trained districts in 2017 (source: from authors).

Table 3. Distribution of trainings' Beneficiaries (source: from authors).

\begin{tabular}{cccccccc}
\hline \multirow{2}{*}{ Regions } & \multirow{2}{*}{ District } & \multirow{2}{*}{ Localities } & \multicolumn{2}{c}{ Technical Services } & \multicolumn{2}{c}{ Fishermen } & \multirow{2}{*}{ Media } \\
\cline { 4 - 6 } & & & Services & Participants & Male & Female & \\
\hline Ziguinchor & Oussouye & Oukoute & 5 & 5 & 20 & 2 & 3 \\
Ziguinchor & Oussouye & Elinkine & 3 & 4 & 29 & 1 & 0 \\
Ziguinchor & Oussouye & Diogué & 3 & 4 & 37 & 2 & 0 \\
Ziguinchor & Bignona & Mangagoulack & 7 & 7 & 37 & 3 & 2 \\
Ziguinchor & Bignona & Thiobon & 5 & 5 & 40 & 2 & 1 \\
Ziguinchor & Bignona & Kalounayes & 7 & 7 & 40 & 1 & 1 \\
Fatick & Fatick & Djiffer & 3 & 8 & 32 & 3 & 1 \\
Fatick & Foundiougne & Foundiougne & 3 & 5 & 38 & 1 & 1 \\
Ziguinchor & Ziguinchor & Ziguinchor & 2 & 16 & 37 & 0 & 3 \\
Ziguinchor & Bignona & Kafountine & 2 & 2 & 37 & 1 & 0 \\
& Total & & $\mathbf{4 0}$ & $\mathbf{6 3}$ & $\mathbf{3 4 8}$ & $\mathbf{1 6}$ & $\mathbf{1 2}$ \\
\hline
\end{tabular}

\subsection{CIS Uptake on the Ground}

The evaluation of decisions taken after the reception of CIS at the beginning of the rainy season is shown in Figure 6. Out of 289 surveyed people, $78 \%$ of the respondents have used the diffused CIS to guide their decision-making at the beginning of the rainy season. The decisions taken are related to the choice of croplands, crop varieties, sowing, ploughing and fertilizer spreading dates. About $43 \%$ decided to plow their field at a specific date, $34 \%$ to sow and $10 \%$ to choose adapted varieties. The results also indicated that $94 \%$ of the respondents have shared the information or knowledge they have gained during the training with their parents, friends and members of their organizations, of which $11 \%$ are women. During the workshop, a farmer from Kolda testified: "I received a message on August 18th indicating that a rain was expected to occur the following day. I have therefore decided to postpone the spread of the fertilizer to avoid losses". Furthermore, a technician from the agricultural extension service in Kolda attested: "After being informed that a rain will occur the following day, a farmer under my supervision did not trust the forecast and went to his cropland and spread $2000 \mathrm{~kg}$ of NPK. A $90 \mathrm{~mm}$ rain 
occurred in the following day and he totally lost his fertilizer. From this date, he keeps on paying attention to the forecasts before any action could be taken".

At the end of the rainy season, the evaluation has revealed that $95.7 \%$ of the respondent farmers were very satisfied with the decision that they have taken following the reception of the CIS and $78.4 \%$ have certified that their crop yield has been substantially improved. In the fisheries sector, the evaluation showed that about $45 \%$ of the respondents decided to postpone their activities on the sea after they received the warning; $15 \%$ decided to go to sea while using their life jacket, less than $1 \%$ took the risk to go to sea without security measures and the rest carried on other activities while waiting for the safe fishing periods to come. Among those who took the decision to avoid the risk, $89 \%$ are confident that they have taken a good decision to save their life, although this decision has negatively impacted their household income.

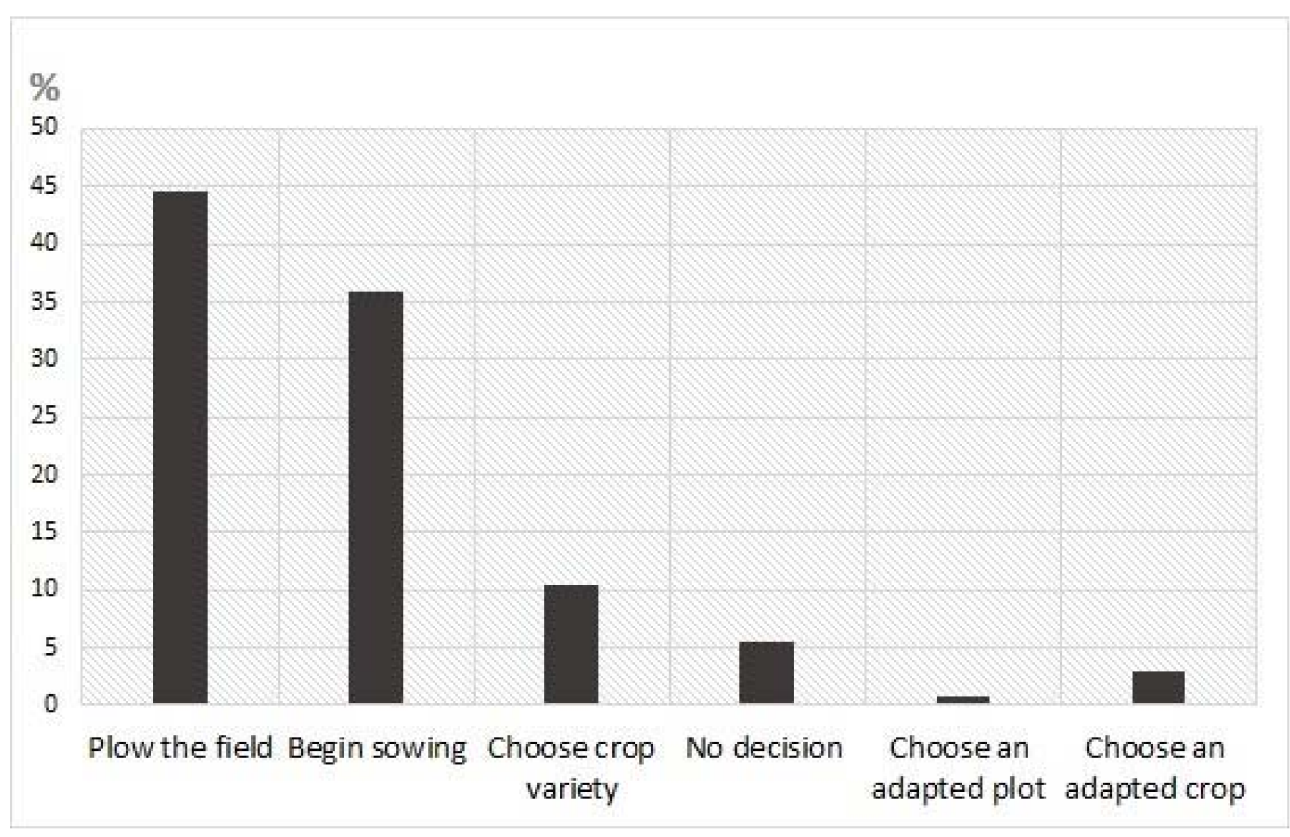

Figure 6. Decision taken after the reception of CIS at the beginning of the rainy season (source: from authors).

The evaluation workshops had given opportunities to farmers who attended the training sessions to express the practical use of the skills they gained, to show the utility of the CIS on the ground, and to make suggestions which they believe could enhance the benefit of the trainings. The lead-farmers perceive the utility of the CIS and are advocating for the wider uptake of the CIS among the other farmers in their respective communities. For instance, participants believe that the outcomes of the trainings will be more valuable if the next training sessions could take into consideration the following recommendations: extending the trainings to two days, the first day on the theoretical aspects and the second day on the practical aspects; delivering the trainings at least one month prior to the start of the rainy season; producing info-graphic manuals for the trainings to be shared to the participants; distributing the seasonal forecast well in advance, at least one month before the onset of the season.

The 62 randomly-selected lead-farmers were trained to understand the principles of the field demonstration. They have received agricultural inputs including improved crop varieties (rice, maize and millet) and fertilizers prior to the onset of the rainy season to be used in their selected one-hectare plot. They have also received the 2017 seasonal forecast which predicted that the season will be humid (rainfall above average). This forecast permitted them to identify suitable cropping plots and crop varieties following the recommendation from the agricultural extension services. During the course of the rainy season, the lead-farmers received relevant and timely instant and weekly rain, temperature and wind forecasts. A field demonstration design was produced for the farmers to apply in their plot 
and a monitoring form of the field demonstration was distributed and regularly filled by the extension staff. Different meetings with involved stakeholders (extensionists, selected farmers and non-selected farmers) were held, during which individual beneficiaries of the field demonstration shared their experiences and lessons learnt and raised issues they encountered.

\subsection{Difficulties Encountered}

Five major constraints have been met during the study period which, if not solved, could undermine the effectiveness of the uptake of CIS. The first has to do with the funding sources for CIS delivery. From the production to the diffusion through the training of the users to understand and strongly use the CIS, there is a huge cost associated that goes beyond the financial capacity of a national meteorological office. During the evaluations, the CIS end-users have mentioned the fact that the trainings did not happen at time suitable for them to gain the full benefit of it. The number of technicians being very limited, some trainings were delivered at periods during which the farmers had started their farming activities. In addition, some CIS were diffused with delay or at a time when it was difficult for the users to take appropriate actions. Preferably, the users request the CIS to be diffused two to three days before the actual occurrence of the event. Despite the efforts made to produce the relevant CIS for the livestock sector, none has been produced. This is due to the complexity of these CIS, which require competences from multiple backgrounds. Finally, although the engagement of the authorities is effective at the district level, this is not yet the case for the policy-makers at the national level.

\section{Discussion}

\subsection{Participatory Training as Way to Building Trust with the CIS Users}

According to Vincent et al. [16], the importance of climate service, i.e., the provision of targeted, tailored and timely weather and climate information, has gained momentum, but it requires a proper understanding of the users' needs. For Lemos et al. [23] and Singh et al. [22], the disconnection between producers and users of climate information is one of the key barriers limiting the uptake of climate information in Africa. Furthermore, Singh et al. [17], Eisenack et al. [32] and Rose [33] argued that, in WA, most CIS initiatives failed because the information produced and disseminated is often ill-suited to inform decision-making at the local scale, particularly for farmers, pastoralists and sub-national governments. The case of Senegal has well taken into account initiatives to narrow the above-cited obstacles by promoting inclusive trainings with the users and involvement of the local authorities. The trainings are crucial not only to build the readiness of the farmers to face the adverse effects of climate change, but also to build the confidence between them and the CIS producers, between the indigenous and scientific weather forecasting systems, and to build their capacity to understand, receive and effectively use the CIS as important agricultural inputs. Along the training sessions, the trainers took the time to listen to the farmers and to understand the facets of their traditional knowledge that might be climate related. Farmers were welcomed as keepers of knowledge passed on from generation to generation and were invited as experts to share their indigenous climate knowledge. The philosophy behind this lies in the fact that scientists would lose credibility if farmers were to think that scientists believe that their elders were wrong and only scientists were right, as supported by Kniveton et al. [34] and Martínez et al. [35]. After listening to farmers, the trainers established the relationships between the two types of knowledge (traditional and scientific) to make farmers confident that their indigenous skills regarding climate change and forecasts are effective. The difference is that the traditional ones are locally grounded while the scientific ones refer to processed data and evidence-based knowledge about the atmosphere-ocean system across short and long time scales [34]. The next step was to explain with easy words and graphics the probabilistic aspect of the weather forecast, to ensure the farmers that the CIS they will receive will have a certain level of uncertainty. 


\subsection{Building the Policy Enabling Environment}

Studies have revealed that one of the limitations that currently impedes the incorporation of climate and weather information into national policy planning and decision-making in WA is the lack of involvement of the local, regional and national levels decision-makers in the climate information governance system $[16,23,33,36,37]$. To incentivize the policy implication in the adoption of the CIS as an important input for the farming, pastoralist and fishery activities in Senegal, the local (Prefects), regional (Governors) and the national (ministries in charge of agriculture, fisheries and livestock management) stakeholders are being involved at all stages of the process. The creation and functionality of the MWGs are, for instance, under the leadership of the Prefects and the prefectural by-laws (decrees) signed during the creation of each MWG are a sign of engagement and commitment of the local authorities to encourage producers to adopt the innovative climate risk management options. The Prefects are respected authorities by communities in the districts under decentralization. Once they are involved in a process of the introduction of new technology, the uptake of this technology by the communities becomes effortless. In fact, the Prefects play the role of "drive belts" between the communities and the Governors of Regions. Therefore, any action they take is conformed to the wellbeing of the communities and to the development plans at the regional level. In general, during the training workshops, the Prefects open the ceremony with a speech, play the role of chairman and close the ceremony while providing an action forward. This implies that for any innovative practice such as the introduction of climate risk management technologies to be effective in African countries, a bottom-up approach, involving the end-users and the next-users (policy-makers) is a prerequisite.

\subsection{Challenges and Opportunities of CIS Upscaling}

Similar to countries such as India and Malawi where weather information is used, Senegal is facing multiple challenges which, if unchecked, could undermine the long-term sustainability of delivery and uptake of CIS. The common issues encountered are: (i) the production of information is not locally relevant, fit-for purpose and available in a timely manner [17,38,39]; (ii) the non-existence of appropriate governance and institutional structures for the provision of climate information [19]; (iii) there is not enough emphasis on socio-economic value in the uptake of climate information provided and subsequent decision-making [40]; and (iv) the lack of appropriate boundary organizations to effectively communicate between information providers and users. There are additional major challenges that are specific to the case of Senegal and these have to do with the funding sources, the production of missing but awaited CIS and the timely implementation of the training on the ground. From the production to the use of CIS on the ground through the diffusion and the functionality of the MWGs, there is a huge associated cost. A sustainable large-scale adoption of CIS use requires sustained financial resources. The overall requested CIS by the pastoralist communities is yet to be produced. This requires an inter-disciplinary work with experts in ecology, biology, pastoralism, geography, climatology, hydrology, etc. and the use of adequate tools and approaches such as remote sensing and geographical information systems (GIS). The training workshops for the end-users of CIS are delivered by the national institution in charge of the meteorological services. The limited number of technicians and the administrative burdens are limiting factors to the timely implementation of the training. It is becoming more and more evident that, to ensure the timely delivery of the training on the ground, the involvement of the private sectors in the system to compensate the limiting number of technicians from the national meteorological office is essential.

Despite these challenges, there are exciting opportunities that augur positive movement. In spite of the recent introduction of the use of the CIS, there has been a move towards a greater uptake of climate information services on shorter time scales, for example, in the agricultural sector, where farmers have taken interesting decisions following the reception of the CIS, and in the fisheries sector where fishermen always postpone journeys to the sea upon reception of information predicting the occurrence of high tides or swells. This has been made possible by dint of the use of the innovative communication channels for a widespread uptake. With the recently operationalized Enhancing 
National Climate Services initiative (ENACTS) in Senegal, that makes use of downscaled climate data ( $4.5 \mathrm{~km}$ resolution) throughout the country, it is expected that local-scale CIS will be produced and communicated to the users. Finally, with the increased interest given to the weather-based index insurance in Senegal for agriculture, fisheries and pastoralism, we believe that the exit strategy for the sustainability of CIS upscaling resides in including the cost for the CIS production and delivery in the insurance subscription package. To this end, a cost-benefit analysis for CIS use and a willingness-to-pay for CIS delivery studies should be performed.

\section{Conclusions}

This paper clearly indicates that, for any new technology to be successfully introduced in rural communities, a bottom-up approach combined with policy-maker involvement at local, regional and national levels is required. The use of participatory methods and the inclusion of indigenous knowledge from the identification of the relevant CIS and communication channels to the training of the users to understand and effectively use the CIS for their production practices has built a mutual trust between the CIS users and providers and enabled the widespread adoption of the technology. This has also enabled the strong engagement of the local, regional and national authorities, thus creating a political enabling environment for the sustainability of the use of CIS. Some challenges do exist and are concerned with the lack of permanent funding sources, the production of downscaled and missing CIS and the timely delivery of CIS and relevant training on the ground.

The Senegal case is an experience that will enrich the documentation on the production and dissemination of CIS, and this will definitely benefit the whole WA sub-region. Recommendations that could contribute to sustaining the system include (1) building a robust database that will include the contact information of the maximum number of producers for them to receive the first hand CIS via their mobile phones; (ii) improving the CIS diffusion system via the community radios (much cheaper) by identifying suitable timing and frequency for users; (iii) involving private sectors in the delivery process of CIS and relevant training on the ground to avoid the limiting number of staff in the public office that creates delays in the delivery of the trainings; and (iv) advocating for a large subscription of the producers to the insurance system so that the costs of CIS production and diffusion/trainings could be incorporated into the primes the producers will pay for.

Acknowledgments: The authors acknowledge the USAID funding support to the CINSERE project in Senegal and we are thankful to the Feed the Future Activities, namely, Naatal Mbay, Yaajeende, COMFISH and ERA for their kind collaboration and the data and information sharing. USAID/CINSERE project is implemented by the CGIAR Research Program on Climate Change, Agriculture and Food Security (CCAFS), a strategic partnership of CGIAR and Future Earth, led by the International Center for Tropical Agriculture (CIAT) and carried out with support from CGIAR Fund Donors and through bilateral funding agreements (For details please visit https: / / ccafs.cgiar.org/donors). We would like to express our deepest gratitude to the technicians of ANACIM who carried out the trainings on the ground.

Author Contributions: Issa Ouedraogo conceived the paper rational, carried data collection and analysis and drafted the paper, Ndeye Seynabou Diouf contributed to the data collection and analysis. Mathieu Ouédraogo, Ousmane Ndiaye and Robert B. Zougmoré contributed to the interpretation of results and discussion. All authors participated to the final draft.

Conflicts of Interest: The authors declare no conflict of interest.

\section{References}

1. Niang, I.; Ruppel, O.; Abdrabo, M.; Essel, A.; Lennard, C.; Padgham, J.; Urquhart, P. Africa. In Climate Change 2014: Impacts, Adaptation and Vulnerability. Contribution of Working Group II to the Fifth Assessment Report of the Intergovernmental Panel on Climate Change; Cambridge University Press: Cambridge, UK, 2014.

2. IPCC. Summary for Policymakers. In Climate Change 2014: Impacts, Adaptation, and Vulnerability. Part A: Global and Sectoral Aspects. Contribution of Working Group II to the Fifth Assessment Report of the Intergovermental Panel on Climate Change; Cambridge University Press: Cambridge, UK, 2014; pp. 1-32. 
3. Serdeczny, O.; Adams, S.; Baarsch, F.; Coumou, D.; Robinson, A.; Hare, W.; Schaeffer, M.; Perrette, M.; Reinhardt, J. Climate change impacts in sub-Saharan Africa: From physical changes to their social repercussions. Reg. Environ. Chang. 2017, 17, 1585-1600. [CrossRef]

4. Jalloh, A.; Nelson, G.C.; Thomas, T.S.; Zougmoré, R.; Roy-Macauley, H. West African Agriculture and Climate Change: A Comprehensive Analysis. IFPRI Research Monograph; International Food Policy Research Institute: Washington, DC, USA, 2013.

5. Aich, V.; Koné, B.; Hattermann, F.F.; Müller, E.N. Floods in the Niger basin-Analysis and attribution. Nat. Hazards Earth Syst. Sci. Discuss. 2014, 2, 5171-5212. [CrossRef]

6. Rosenzweig, C.; Elliott, J.; Deryng, D.; Ruane, A.C.; Müller, C.; Arneth, A.; Boote, K.J.; Folberth, C.; Glotter, M.; Khabarov, N.; et al. Assessing agricultural risks of climate change in the 21st century in a global gridded crop model intercomparison. PNAS 2014, 111, 3268-3273.

7. UNDESA. Volume I: Comprehensive Tables. In World Population Prospects: The 2012 Revision; UN Department of Economic and Social Affairs (UNDESA): New York, NY, USA, 2013.

8. Mueller, N.D.; Gerber, J.S.; Johnston, M.; Ray, D.K.; Ramankutty, N.; Foley, J.A. Closing yield gaps through nutrient and water management. Nature 2012, 490, 254. [CrossRef] [PubMed]

9. Ouedraogo, I.; Runge, J.; Eisenberg, J.; Barron, J.; Sawadogo-Kaboré, S. The re-greening of the Sahel: Natural cyclicity or human-induced change? Land 2014, 3, 1075. [CrossRef]

10. Ouedraogo, I.; Barron, J.; Tumbo, S.D.; Kahimba, F.C. Land cover transition in northern Tanzania. Land Degrad. Dev. 2016, 27, 682-692. [CrossRef]

11. Douxchamps, S.; Ayantunde, A.; Barron, J. Taking stock of forty years of agricultural water management interventions in smallholder systems of Burkina Faso. Water Resour. Rural Dev. 2014, 3, 1-13. [CrossRef]

12. Barron, J.; Okwach, G. Run-off water harvesting for dry spell mitigation in maize (Zea mays L.): Results from on-farm research in semi-arid Kenya. Agric. Water Manag. 2005, 1-21. [CrossRef]

13. De Bruin, A.; Pateman, R.; Barron, J.; Balima, M.; Ouedraogo, I.; Da Dapola, E.; Fosu, M.; Annor, F.O.; Magombeyi, M.; Kileshye Onema, J.-M. Setting up agricultural water management interventions—Learning from successful case studies in the Volta and Limpopo river basins. Water Resour. Rural Dev. 2015, 6, 12-23. [CrossRef]

14. Rockstrom, J. Water resources management in smallholder farms in eastern and southern Africa: An overview. Phys. Chem. Earth Part B Hydrol. Ocean. Atmos. 2000, 25, 275-283. [CrossRef]

15. Hackenbruch, J.; Kunz-Plapp, T.; Müller, S.; Schipper, J. Tailoring climate parameters to information needs for local adaptation to climate change. Climate 2017, 5, 25. [CrossRef]

16. Vincent, K.; Dougill, A.J.; Dixon, J.L.; Stringer, L.C.; Cull, T. Identifying climate services needs for national planning: Insights from Malawi. Climate Policy 2017, 17, 189-202. [CrossRef]

17. Singh, C.; Daron, J.; Bazaz, A.; Ziervogel, G.; Spear, D.; Krishnaswamy, J.; Zaroug, M.; Kituyi, E. The utility of weather and climate information for adaptation decision-making: Current uses and future prospects in Africa and India. Climate Dev. 2017. [CrossRef]

18. Kusangaya, S.; Warburton, M.L.; Archer van Garderen, E.; Jewitt, G.P.W. Impacts of climate change on water resources in southern Africa: A review. Phys. Chem. Earth Part A/B/C 2014, 67-69, 47-54. [CrossRef]

19. Vaughan, C.; Dessai, S. Climate services for society: Origins, institutional arrangements, and design elements for an evaluation framework. Wiley Interdiscip. Rev. Climate Chang. 2014, 5, 587-603. [CrossRef] [PubMed]

20. UNPP. New Vision for Weather and Climate Information Services in Africa; United Nations Development Programme: New York, NY, USA, 2016.

21. Zongo, B.; Diarra, A.; Barbier, B.; Zorom, M.; Yacouba, H.; Dogot, T. Farmers' perception and willingness to pay for climate information in Burkina Faso. J. Agric. Sci. 2015. [CrossRef]

22. Singh, C.; Dorward, P.; Osbahr, H. Developing a holistic approach to the analysis of farmer decision-making: Implications for adaptation policy and practice in developing countries. Land Use Policy 2016, 59, 329-343. [CrossRef]

23. Lemos, M.C.; Kirchhoff, C.J.; Ramprasad, V. Narrowing the climate information usability gap. Nature Climate Chang. 2012, 2, 789. [CrossRef]

24. Akinnagbe, O.M.; Irohibe, I.J. Agricultural adaptation strategies to climate change impacts in Africa: A review. Bangladesh J. Agric. Res. 2014, 39, 407-418. [CrossRef] 
25. Mbow, C.; Smith, P.; Skole, D.; Duguma, L.; Bustamante, M. Achieving mitigation and adaptation to climate change through sustainable agroforestry practices in Africa. Curr. Opin. Environ. Sustain. 2014, 6, 8-14. [CrossRef]

26. Zougmoré, R.; Partey, S.; Ouédraogo, M.; Omitoyin, B.; Thomas, T.; Ayantunde, A.; Ericksen, P.; Said, M.; Jalloh, A. Toward climate-smart agriculture in west Africa: A review of climate change impacts, adaptation strategies and policy developments for the livestock, fishery and crop production sectors. Agric. Food Secur. 2016, 5, 26. [CrossRef]

27. FAO. Senegal: Country Fact Sheet on Food and Agriculture Trends; FAO: Rome, Italy, 2015.

28. CIAT; BFS/USAID. Climate-Smart Agriculture in Senegal. CSA Country Profiles for Africa Series; International Center for Tropical Agriculture (CIAT), Bureau for food security, United States Agency for International Development (BFS/USAID): Washington, DC, USA, 2016.

29. Colen, L.; Demont, M.; Swinnen, J. Smallholder participation in value chains: The case of domestic rice in Senegal. In Rebuilding West Africa's Food Potential; Elbehri, A., Ed.; FAO/IFAD: Rome, Italy, 2013.

30. APRAPAM. Pêche : Oumar guèye annonce la construction de 19 unités de transformation. Available online: http:/ / www.Aprapam.Org/senegal/securite-en-mer/ (accessed on 12 December 2017).

31. Pontius, J.; Dilts, R.; Bartlett, A. From Farmer Field School to Community IPM: Ten Years of IPM Training in Asia; FAO: Bangkok, Thailand, 2002; p. 110.

32. Eisenack, K.; Moser, S.C.; Hoffmann, E.; Klein, R.J.T.; Oberlack, C.; Pechan, A.; Rotter, M.; Termeer, C.J.A.M. Explaining and overcoming barriers to climate change adaptation. Nature Climate Chang. 2014, 4, 867. [CrossRef]

33. Rose, D.C. Five ways to enhance the impact of climate science. Nature Climate Chang. 2014, 4, 522. [CrossRef]

34. Kniveton, D.; Visman, E.; Tall, A.; Diop, M.; Ewbank, R.; Njoroge, E.; Pearson, L. Dealing with uncertainty: Integrating local and scientific knowledge of the climate and weather. Disasters 2015, 39, S35-S53. [CrossRef] [PubMed]

35. Martínez, R.; Hemming, D.; Malone, L.; Bermudez, N.; Cockfield, G.; Diongue, A.; Hansen, J.; Hildebrand, A.; Ingram, K.; Jakeman, G.; et al. Improving climate risk management at local level-Techniques, case studies, good practices and guidelines for world meteorological organization members. In Risk Management-Current Issues and Challenges; Nerija, B., Ed.; InTechOpen: University Campus STeP Ri, Croatia, 2012.

36. Demeritt, D.; Langdon, D. The UK climate change programme and communication with local authorities. Glob. Environ. Chang. 2004, 14, 325-336. [CrossRef]

37. Mase, A.S.; Prokopy, L.S. Unrealized potential: A review of perceptions and use of weather and climate information in agricultural decision making. Weather Climate Soc. 2014, 6, 47-61. [CrossRef]

38. Lackstrom, K.; Kettle, N.P.; Haywood, B.; Dow, K. Climate-sensitive decisions and time frames: A cross-sectoral analysis of information pathways in the Carolinas. Weather Climate Soc. 2014, 6, 238-252. [CrossRef]

39. Nidumolu, U.B.; Lubbers, M.; Kanellopoulos, A.; van Ittersum, M.K.; Kadiyala, D.M.; Sreenivas, G. Engaging farmers on climate risk through targeted integration of bio-economic modelling and seasonal climate forecasts. Agric. Sys. 2016, 149, 175-184. [CrossRef]

40. Dorward, P.; Clarkson, G.; Stern, R. Participatory Integrated Climate Services for Agriculture (PICSA): Field Manual; Walker Institute, University of Reading: Reading, UK, 2015.

(C) 2018 by the authors. Licensee MDPI, Basel, Switzerland. This article is an open access article distributed under the terms and conditions of the Creative Commons Attribution (CC BY) license (http://creativecommons.org/licenses/by/4.0/). 